\title{
Moral Law Vs. Conscience in the Veritatis Splendor*
}

The emergence of what may be referred to as the "new humanism" caused, as if by reflection, a crisis of classic Christian morality, undermined in its very essence. This new humanism is founded on considering human freedom as the only and absolutely most important value which has to be first acknowledged and respected. According to this way of thought, a human stops considering him- or herself a person who is given in a natural, timeless way, who is completely constituted, but to the contrary - he or she starts to increasingly better understand that he or she may define him- or herself on his or her own because he or she is called to create him- or herself ${ }^{1}$.

Placing the main emphasis on freedom and on the necessity to take into consideration a particular situation, deprives ethics of the objective basis of moral value and shifts it to the position of extreme subjectivism. Therefore, there is clear reluctance towards formulating common and unchanging moral principles. This is followed by adopting an existential way of perceiving human nature, which continuously undergoes changes and creates itself ${ }^{2}$. In this concept, human nature is relative and changeable and cannot be considered objective. Nature understood this way also cannot be the basis for deriving the existence of objective, commonly applicable norms and principles. Transferring these thoughts to the ground of human calling, it is necessary to, in consequence, say that the calling addressed to human by God - an individual and direct calling - takes place, generally, irrespectively of the objective moral order. Every person individually and in every situation stands before a free decision and action $^{3}$, which are required

STV 32(1994)1.

Cf. T. Styczeń, Prawda o człowieku miara jego afirmacji, "Communio" 4(1982)10, 111ff.

Cf. S. Rosik, Wezwania i wybory moralne. Refleksje teologicznomoralne, Lublin 1992, 25.

3 This concept of a human is related to by B. Häring, Frei in Christus, vol. 1., Freiburg im Breisgau 1979, $352 \mathrm{ff}$. 
from him or her by the current situation. Conscience, in turn, based on the situation and internal intuition, and not based on objective moral law, judges what should be considered as senseful and good ${ }^{4}$.

An inevitable result of such a state of affairs is an attempt to deify a human by proposing to him or her such a philosophy in which he or she creates him- or herself on his or her own, in both, his or her ontological being as well as in the system of ethical values. This kind of anthropological orientation, consciously eliminating the existence of objective and absolutely applicable ethical norms, is based only on provisional ethics and promises salvation for the price of the appropriation of human conscience and human dignity. These and other thought directions are based on the incorrect interpretation of conscience, and by introducing separation between freedom and law; they lead to moving away from the stand of the Church and of its Magisterium in the basic issues of defining Christian morality. Therefore, it is justified to become familiar with John Paul II's teaching on matters of conscience and moral law.

\section{God as the Creator of Moral Law}

Veritatis splendor which recalls the basic issues of the moral teaching of the Church, attempts to emphasize what is significant in that teaching. Undoubtedly, a significant problem in defining authentic Christian morality is acknowledging, or not, God as the Author of moral law. The fundamental statement of the Encyclical on this matter is the following: "Moral law has God as its author, and (...) man, by the use of reason, participates in the eternal law, which it is not for him to establish" (VS 36).

The aim of the above statement is recalling the whole Tradition of the Church, that moral order is not the work of our independent autonomy imposing moral law. The content of that law results from the essence of our being but does not exist independently of our will. We do not give moral law to ourselves, but we discover them ${ }^{5}$. True moral autonomy, compliant with the Catholic doctrine consists in the fact that human freedom and God's law meet and mutually

4 According to T. Styczeń: "A very meaningful example of that is the language of certain moralists which discuss conscience. The judgment of conscience (Gewissensurteil) is being replaced by a truth-creating decision of the conscience. Gewissensentscheidung completely absorbs the functions assigned to Gewissensurteil," art. cit., 112.

5 Many people know the famous saying of one of Sartre's characters: "I am doomed to have no other law but mine. (...) I must blaze my trail. For I, Zeus, am a man, and every man must find 
interpenetrate. Natural law, i.e. the participation of intelligent creation in the eternal law of God means the general subordination of the reason - and of the moral commandments resulting from it - to God's Wisdom (cf. VS 35). The Encyclical confirms, against any relativisms, the universal and permanent nature of the ordinances of moral law which express the original truth about the good of a person and show the way of the authentic implementation of freedom. The Encyclical aims at reminding those who define Christian morality, about the dependence of reason on God's Wisdom and about the necessity of God's Revelation in becoming aware of moral truths, also those which belong to the natural order (cf. VS 36). This reminding is caused by the existence of certain theories which proclaim complete sovereignty of reason in the area of moral norms. In the light of these theories, these norms would be the expression of a law "which man in an autonomous manner lays down for himself and which has its source exclusively in human reason" (VS 36$)^{6}$.

In the light of the Encyclical, the autonomy of morality cannot mean its complete sovereignty and ignoring any authorities. Every person has to be aware of his or her own fallibility, of the limited capability of his or her cognition, including also the understanding of the deepest origins of good and evil. What is rational is taking into consideration the limitations of one's own possibilities and subordinating to an authority. The basis for such an attitude is the conviction that it is not human who decides on what is good or evil, but humans hold guard of what is good and is - due to various reasons - not recognized as good by everyone ${ }^{7}$.

Therefore, the possible moral ordinances included in the Revelation, and not understandable fully in the scope of natural cognition, do not infringe on human autonomy. On the one hand, moral life requires creative thinking and the intelligence which is the characteristic of a person, on the other hand, however, reason draws its truth and its authority from the eternal law of God (cf. VS 40).

out his own way," Dramaty (...) Muchy, dramat w trzech aktach (Drama: The Flies), translated from French into English by S. Gilbert, translated into Polish by: J. Lisowski, Warszawa 1956, 102.

6 The concept of creative reason as the guiding idea of the new moral theology has received much attention from A. Szostek, who, moreover, indicates theologians who, in assumptions, especially anthropological ones, have followed such a trend. Cf. Natura-rozum-wolność. Filozoficzna analiza koncepcji twórczego rozumu we współczesnej teologii moralnej, Rome 1990, 81-244.

7 "Unlike the classic understanding of philosophical anthropology, the anthropologies according to which the image of human or human nature constitute the correlate of the self-understanding of an individual or of a social group, simply eliminate the need and necessity of referring it to transcendent truth, i.e. any further validation (verification).” T. Styczeń, art. cit., 110. 
The legitimate autonomy of practical reason means that a human has his or her own law within him- or herself, however, this is law received from the Creator. Such autonomy of reason does not mean that reason itself may create values and moral norms. Similarly, true and legitimate human moral autonomy does not imply the rejection of moral law, the natural and the revealed one. Autonomy understood this way does not lead to the denial of the participation of practical reason in the Wisdom of the Creator and Divine Legislator and does not indicate the freedom of creating moral norms depending on the historical circumstances or the needs of various societies and cultures ${ }^{8}$.

By emphasizing the legitimate human moral autonomy, the Encyclical very clearly demonstrates that humans - due to the fact that moral law comes from God and has always its source in Him - cannot perform free self-design. A human cannot grant sense to him- or herself as well as to the surrounding world 9 . By adopting self-design as the basic criterion for the sense and the moral value of an act, it would be necessary to say that a human must on his or her own make a free decision regarding who he or she will be and how he or she will direct the history of him- or herself and of the world. In accordance with such an assumption, the personal human subject is called to create, not discover, the truth about him- or herself and to be also able to, on his or her own, reach the moral assessment of particular situations ${ }^{10}$.

According to the Encyclical, for humans, obedience to God's law guarantees remaining in truth and it fully corresponds to human dignity. While referring to God's moral law, the Encyclical represents the stand of the unity of the creation and the Covenant. For God is the creator of the natural and the revealed law. For God, everything is unity, there is one eternal plan of God which is the basis of all the history of the world. "The different ways in which God, acting in history, cares for the world and for mankind are not mutually exclusive; on the contrary, they support each other and intersect" (VS 45). This happens because their common source and aim is the eternal plan, full of wisdom and love, whereby God directs and governs the whole world and the paths of the

$8 \quad$ "If by the autonomy of earthly affairs we mean that created things and societies themselves enjoy their own laws and values which must be gradually deciphered, put to use, and regulated by men, then it is entirely right to demand that autonomy. (...) But if the expression, the independence of temporal affairs, is taken to mean that created things do not depend on God, and that man can use them without any reference to their Creator, anyone who acknowledges God will see how false such a meaning is. For without the Creator the creature would disappear." GS 36.

9 Cf. A. Szostek, op. cit., 151.

10 Cf. Ibid., 154. 
human community. The Encyclical performs a certain synthesis which unifies the imperatives of the moral realm: the natural moral law reproduces the idea of creation, which established the purposefulness of human nature, whereas the "new law" of Christ reproduces the idea of salvation and demonstrates God's will. This "new Law," which is the fulfillment of God's law in Jesus Christ and in His Spirit, in the act of eternal love, calls humans to co-participate in its divine life through perfection of the highest degree. The obliging power of these laws derives from the eternal law which is God, communicating His calling to the human conscience ${ }^{11}$.

\section{Conscience as the Condition of Human Freedom}

The implementation of moral good assumes human freedom. "Authentic freedom is an exceptional sign of the divine image within man. For God has willed that man remain "under the control of his own decisions, so that he can seek his Creator spontaneously, and come freely to utter blissful perfection through loyalty to Him. Hence man's dignity demands that he act according to a knowing and free choice that is personally motivated and prompted from within, not under blind internal impulse nor by mere external pressure" (GS 17). A human is called to free and morally good action, above all, through his or her conscience.

John Paul II realizes the fact that the bond between human freedom and God's law finds its realization in conscience, and the fact that the relationship between freedom and law is closely related with the concept of conscience. In order to present the essence of conscience, the Encyclical refers to the teaching of the Second Vatican Council, where the following was said: "In the depths of his conscience, man detects a law which he does not impose upon himself, but which holds him to obedience. Always summoning him to love good and avoid evil, the voice of conscience when necessary speaks to his heart: do this, shun that. For man has in his heart a law written by God; to obey it is the very dignity of man; according to it he will be judged" (GS 16).

The Church's teaching about conscience indicates several significant elements. Conscience is, above all, the act of a person who stands before a moral decision and must make this decision. Conscience appears as a voice calling a human to choose good in freedom and in the awareness of full responsibility towards God. In Conscience, the encounter between God and human is fulfilled 
and conscience becomes a place of dialogue. The voice of conscience further presents the call to that dialogue, the beginning of which is given to a human in the act of creation and a person's task is to personally undertake that dialogue and conduct it ${ }^{12}$.

The Encyclical strongly highlights that the dignity of conscience and therefore the dignity of a human being, results, above all, from the fact that conscience discovers moral law which has been written in the human heart by God (cf. Rom 2:14-15). By referring to the words of St. Paul, the Encyclical states that conscience places humans before law, and it becomes a witness in that human's case; a witness of faithfulness or unfaithfulness to the law. Therefore, conscience allows a human to become familiar with the postulates of the wisdom and love of God. Thanks to this, it, in an obliging way, presents to a human the path which he or she should take, granting sense to his or her life. Therefore a human does not only have to rely on his or her own guesses and speculations which are subject to mistakes and failures. Conscience does not enclose a human in being alone, but it makes him or her able - without the fear of undertaking a risk of making a mistake - to become familiar with God's will expressed in law, to which human should show obedience ${ }^{13}$.

The nature of the judgment of conscience is imperative. A human should act in accordance with it. It is the assessment of a concrete situation, however, based on a rational conviction that one has to love and do good and avoid evil (cf. VS, no. 59). Conscience is able to connect people in the search for truth and in resolving - on the way to this truth - moral problems, both, unitary and collective ones. However, the condition is, on the one hand, faithfulness to conscience, and on the other - the rectitude of the conscience which is obedience to the voice of conscience which has been shaped in accordance with the principles of the objective moral norm. The Encyclical highlights that thanks to conscience, (natural) law is applied to a particular case. "The judgment of conscience states 'in an ultimate way' whether a certain particular kind of behavior is in conformity with the law; it formulates the proximate norm of the morality of a voluntary act, 'applying the objective law to a particular case"' (VS 59).

In order not to lose its dignity and, at the same time, freedom, conscience must appropriately read the content and value of moral law. The Encyclical reminds us that natural moral law derives from the very essence of God, and it is discovered and familiarized with based on the very nature of things and the

12 Cf. W. Poplatek, Godność sumienia na podstawie Konstytucji II Soboru Watykańskiego o Kościele w świecie współczesnym, “Analecta Cracoviensia” 2(1970), 249-254.

13 Cf. S. Rosik, Sumienie - głos Boga w człowieku, "Katecheta” 15(1971), 49-59. 
essence of a human being. By proceeding in accordance with the ordinance of conscience we experience that this law becomes our own, personal law, and not an external imposed imperative. However, always, the judgment of the conscience does not "establish the law; rather it bears witness to the authority of the natural law and of the practical reason with reference to the supreme good" (VS 60).

In relation to that we can say that conscience is a voice calling a human to discover the truth about him- or herself ${ }^{14}$, truth which demonstrates the attitude of the acts which have been performed or are to be performed towards who the human really should be. By fulfilling an act, human fulfills him- or herself in that act, for he, as human, as a person, becomes good or evil. The function of conscience consists in defining true good in an act. The freedom, which is guaranteed to conscience here, always includes the dependence on truth. The measure of the maturity and responsibility of the judgments of conscience will not be the pursuit to set it free from objective truth, which ultimately leads to the autonomy of its decisions, but intense searching for truth and being directed by truth in action ${ }^{15}$.

The judgment of conscience does not establish the law, but only certifies the authority of natural law and practical reason in reference to objective good. Conscience cannot be considered as autonomous and the sole source of establishing what is good and what is evil (cf. VS 60). The Encyclical definitely rejects any kind of creative interpretation of conscience (cf. VS 54). The Encyclical does not mention particular representatives of such a thought direction, but it is generally said that, according to some theologians, it is not possible to, in case of all cases, apply general moral norms because the particular reality is so rich that actually every person is left with making a personal decision regarding how he or she should proceed. The existing general norms "are not so much a binding objective criterion for judgments of conscience, but a general perspective which helps man tentatively to put order into his personal and social life" (VS 55).

The creative nature of conscience results, above all - according to some opinions - from the fact of connecting conscience with the whole sphere of psyche and feelings, human historicity and his or her influence on the social and cultural environment. All this becomes a constitutive element of human nature.

14 Cf. A. Szostek, Sumienie a prawda i wolność, “W drodze” 110(1982)10, 48.

15 By rejecting the objectively binding moral order, one has to, due to necessity, refer only to a purely personal, subjective criterion of good and evil. A personal and internal conviction not only shows, but ultimately determines the good and evil of an act, without the need to refer to a different instance, to an objective norm. The decisions of conscience then become fully creative acts. Cf. S. Olejnik, Dar-Wezwanie-Odpowiedź. Teologia moralna, vol. 3, Warsaw 1988, $125 \mathrm{ff}$. 
Absolutely important - especially detailed ethical norms - must be considered impossible. The principles of moral action, functioning in societies, have got a sense only as an expression of the experience of the history of people's coexistence until now. Therefore, they have only got the nature of advice, tips, however, never of absolutely binding norms.

Due to necessity, these kinds of assumptions must lead to adopting the position of ethical situationism ${ }^{16}$. According to this system, the determining and ultimate norm of action is actually not an order which is objective, defined by the law of nature and known in a sure way based on that law, but some internal judgment and the light of reason of every individual human, through which he or she is made aware what he or she is supposed to do when being in a particular situation. The final decision of a human is not an application of objective law to a particular case, but it is direct light and judgment. This judgment, in reference to its objective rightness and veracity, is not, ultimately, measured using any objective norm, but using personal conviction.

The assumption for the above statements is the notion of "existential nature," which actually is changeable, maybe besides only a few elements which belong in it to "metaphysical nature." Similarly, natural law should be considered changeable because only through the autonomous making of particular decisions may a person achieve moral perfection (cf. VS 55). Only when every person is able to, in his or her conscience, judge, not according to objective laws but via individual and personal conviction, what he or she should do in the current situation, will he or she protect him- or herself and free people from numerous ethical conflicts which would otherwise be impossible to resolve.

Creative interpretation of conscience has its far-reaching consequences in building ethics and moral theology. Humans may do all they can in order to be able to implement their free design. He or she is actually not bound by anything. He or she is not bound by his or her own nature because the only thing which is constant in humans are the choices which are prior in reference to any acts. The personal human subject is autonomous towards bio-physiological laws, towards metaphysics, and even towards faith. A human is simply called to create the truth about him- or herself and conscience would be the final instance judging what is good or evil. Taking into consideration especially so-called pastoral cases, one could justify certain solutions which are contrary to the teaching of the Magisterium, or even reach the conviction that the negative norm is not in all cases binding for conscience.

16 This problem is discussed very broadly by S. Rosik, Sytuacjonizm etyczny a chrześcijańska roztropność. Studium teologiczno-moralne, Poznań 1986. 


\section{Deciding on What is Good or Evil Does Not Belong to Human}

The rich heritage of moral reflection elaborated by the Magisterium of the Church, especially in the last century, and referring to various areas of human life, must, today, face the challenge of a new situation which became shaped in the womb of society and of the Christian community itself. Out of the inspiration of the Second Vatican Council, the great and praise-deserving effort of renewing moral theology (OT 16) was undertaken, at the same time, however, there has been a spread - also in Catholic moral theology - of various kind of doubts and reservations towards the moral teaching of the Church; with time it was becoming increasingly more obvious that these are not signs of partial and interim criticism towards concrete moral norms, but an attempt of a global and systematic questioning of the whole heritage of the moral doctrine based on certain anthropologic and ethical concepts.

The Encyclical draws attention to the existence of a moral crisis and to the fact that Christians themselves take various stands towards traditional morality. This is undoubtedly contributed to by certain theologians who reject traditional teaching about natural law, about the commonness and unchanging validity of its ordinances. What is also being questioned is the right of the Magisterium to resolve moral issues and to provide reliable teaching about the absolutely obligatory requirements of God's commandments. Many also claim that it is possible to love God and your neighbor, without being obliged - always and in all circumstances - to observe the norms proclaimed by the Church. Another thing that is being questioned is the existence of an internal and inseparable connection between faith and morality; this is even done by proclaiming the possibility of certain forms of pluralism which are irreconcilable with the Church's communion.

While establishing relationships of moral law towards conscience, the Encyclical asks itself a question which is of fundamental significance for ethics, namely, does human have the power to establish law referring to him- or herself. This question may be answered by referring to facts. From the point of view of experience it has to be noticed that a human, who, as a person, is someone so worthy that he or she should be affirmed for him- or herself, does not stop being someone only very fragile. In order to secure the dignity of a human person, ethics and moral theology have to, on one hand, become familiar with the conditions which are necessary for a human to start existing, and on the other hand, in turn, become familiar with the elements which, in a necessary way, define his or her being-identity, i.e. his or her ontic-axiological structure. 
Becoming familiar with both of these will allow ethics to form normative protections, going below which is absolutely impossible ${ }^{17}$.

By adopting such an anthropology, the Encyclical recalls the words of the Second Vatican Council: "the highest norm of human life is the divine law-eternal, objective and universal-whereby God orders, directs and governs the entire universe and all the ways of the human community by a plan conceived in wisdom and love" (DH 3). Conscience, in turn, formulates the moral duty in the light of that law of God. The universal nature of God's law and of the obligation is not abolished but confirmed by the fact that reason defines their application to a particular situation (VS 59).

These truths and such an anthropology are adopted by the Encyclical Veritatis Splendor. This anthropology, without resigning from examining human in the aspect of the fragility of his or her existence, simultaneously defines the content-elements which are necessary for the identity of the human phenomenon. Based on this anthropology, ethics and moral theology are able to formulate - besides the absolutely important main moral principle - also absolutely important detailed norms of action. For human they define the field of life in truth and they are a safeguard of his or her identity. For Catholics, in turn, the Magisterium of the Church is helpful in discovering truth and moral good. "For the Church is, by the will of Christ, the teacher of the truth. It is her duty to give utterance to, and authoritatively to teach, that truth which is Christ Himself, and also to declare and confirm by her authority those principles of the moral order which have their origins in human nature itself" (DH 14).

Acknowledging the absolute nature of moral norms is of fundamental significance for an individual and for the shaping of his or her conscience in the light of the Truth. Human's orientation in moral matters, despite all the individuality of each person, takes place only within the Church community. "The Church's firmness in defending the universal and unchanging moral norms is not demeaning at all. Its only purpose is to serve man's true freedom. Because there can be no freedom apart from or in opposition to the truth, the categorical (...) defense of the absolutely essential demands of man's personal dignity must be considered the way and the condition for the very existence of freedom" (VS 96). 